\title{
The effects of seasonal climate changes in the Caatinga on tannin levels in Myracrodruon urundeuva (Engl.) Fr. All. and Anadenanthera colubrina (Vell.) Brenan
}

\author{
Júlio M. Monteiro ${ }^{1}$, Ulysses P. Albuquerque ${ }^{1 *}$, Ernani M.F. Lins Neto ${ }^{1}$ Elcida L. Araújo ${ }^{1}$, \\ Miracy M. Albuquerque ${ }^{2}$ Elba L.C. Amorim ${ }^{2}$ \\ ${ }^{1}$ Laboratório de Etnobotânica Aplicada, Departamento de Biologia, Universidade Federal Rural de Pernambuco, \\ Av. Dom Manoel de Medeiros s/n, Dois Irmãos, 52171-900, Recife, PE, Brazil, \\ ${ }^{2}$ Departamento de Ciências Farmacêuticas, Centro de Ciências da Saúde, Universidade Federal de Pernambuco, \\ Av. Prof. Nelson Chaves s/n, Cidade Universitária, 50670-901, Recife, PE, Brazil
}

\begin{abstract}
RESUMO: "Os efeitos da sazonalidade climática na Caatinga sobre os teores de taninos em Myracrodruon urundeuva (Engl.) Fr. All. e Anadenanthera colubrina (Vell.) Brenan". Examinou-se a influência da sazonalidade climática sobre as concentrações de taninos em duas espécies da Caatinga: Myracrodruon urundeuva (Engl.) Fr. All. e Anadenanthera colubrina (Vell.) Brenan. Empregou-se o método Folin-Ciocalteau para quantificar os fenóis totais e o método de precipitação da caseína para taninos. De maneira geral, existe uma forte relação entre os teores de taninos e a pluviosidade, apesar das espécies parecerem adotar diferentes estratégias de produção de compostos tânicos em resposta aos períodos de seca e chuva na caatinga.
\end{abstract}

Unitermos: Florestas secas, Folin-Ciocalteau, plantas medicinais, semi-árido.

\begin{abstract}
The influence of seasonal climatic changes on tannin concentrations was examined in two caatinga (semi-arid) plant species (Myracrodruon urundeuva (Engl.) Fr. All. and Anadenanthera colubrina (Vell.) Brenan). The Folin-Ciocalteau method was used to quantify total phenols, and the casein precipitation method was used for tannins. In general, there is a close relationship between tannin levels and rainfall, although species seem to adopt different strategies of tannin compound production in response to periods of drought and rainfall in the caatinga.
\end{abstract}

Keywords: Dry forest, Folin-Ciocalteau, medicinal plant, semi-arid.

\section{INTRODUCTION}

It is well documented that some ecological variables can quantitatively and qualitatively affect tannin production in plants (Hatano et al., 1986; Teixeira et al., 1990; Furlan et al., 1999; Simon et al., 1999; Salminen et al., 2001; Paiva et al., 2002). Seasonal changes, for example, alter plant metabolism and, consequently, biosynthetic pathways (Hatano et al., 1986; Salminen et al., 2001). Periods of high temperatures are known to increase the concentration of phenolic compounds in many plants. Species of Lotus, for example, demonstrate seasonal variations in tannin concentration (Gebrehiwot et al., 2002), which have been shown to be significantly higher during the spring and summer. The same response was seen with Alnus rubra Bong (González-Hernández et al., 2000). Comparisons between plants growing in tropical sub-humid and tropical semi-arid regions of Africa have demonstrated that total phenols levels increase in regions with more severe climates and with less available humidity (Makkar; Becker, 1998).

In Brazil, only a limited number of studies have examined the influence of environmental variables on tannin production, and most of these have focused on plant defenses in areas of cerrado (savannah) and Atlantic Coastal Forest vegetation (Pais; Varanda, 2003; Pansera et al., 2003; Yariwake et al., 2005). Fewer studies have been undertaken in the caatinga yet and it certainly remains the most incompletely studied Brazilian biome. The caatinga is also the least protected region in Brazil, with less than $2 \%$ of its lands included within any type of conservation area. Research programs in this semiarid region are therefore necessary, especially in light of the rapid alteration of this biome, and substitution of the native vegetation even before it can be effectively studied (Fernandes, 2002; Giullieti et al., 2002; Castelletti et al., 2003).

In the present work, the tannin levels of two caatinga medicinal plants, Myracrodruon urundeuva (Engl.) Fr. All. and Anadenanthera colubrina (Vell.) Brenan, were quantified and compared with local seasonal rainfall data. Studies which increase our understanding of the behavior of caatinga plants are extremely important at this moment for conservation and sustainable. Management strategies are needed to protect and preserve many semi-arid species threatened with

ISSN 0102-695X 

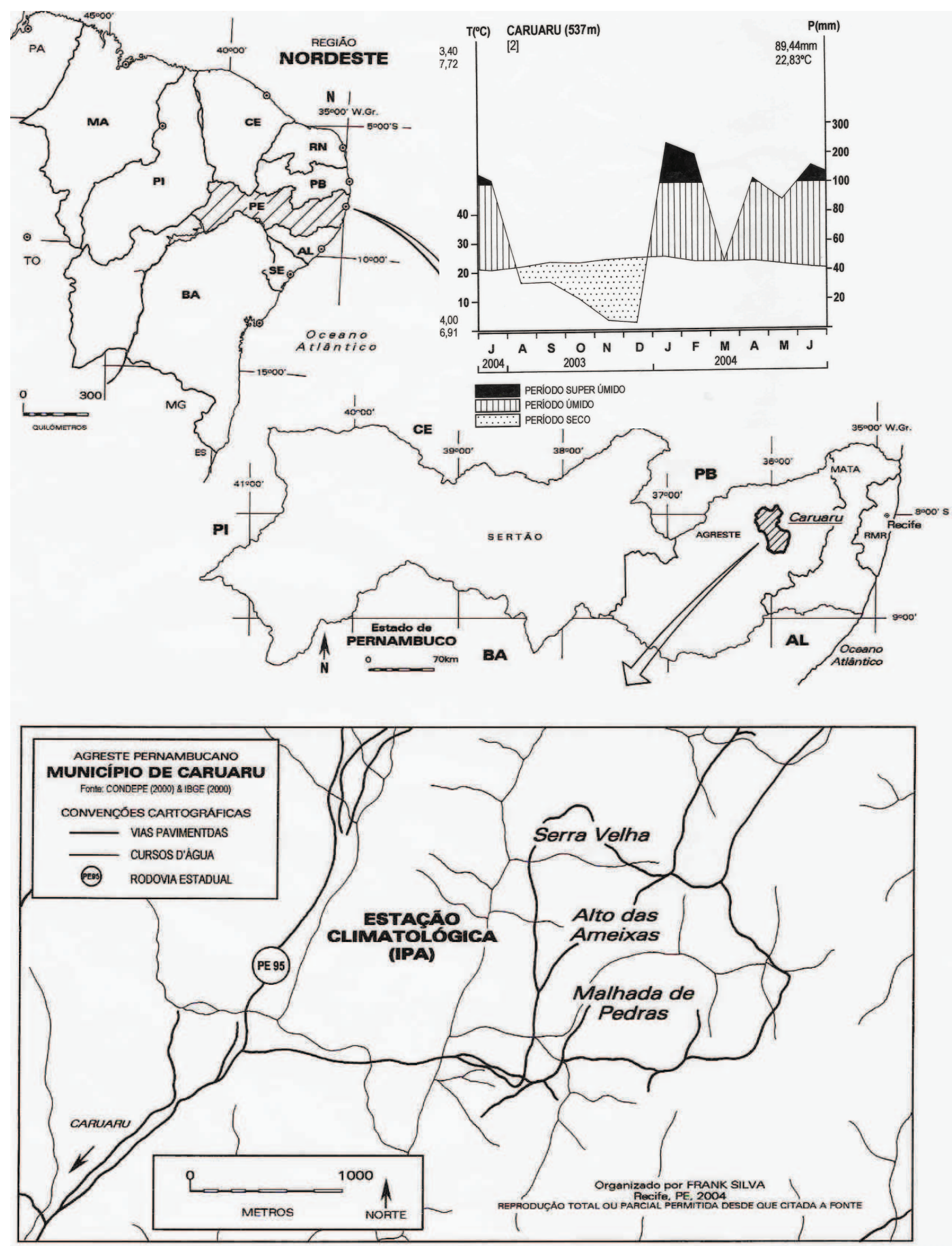

Figure 1. Localization of the communities "Riachão de Malhada de Pedra" and "Alto das Ameixas" within the municipality of Caruaru, Pernambuco State, Brazil, with climograph for the research period - August 2003 to July 2004 (data furnished by the Estação Climatológica do Instituto de Pesquisas Agropecuárias, IPA).

extinction (Monteiro et al., 2005a,b; 2006). Additionally, many secondary metabolic compounds involved in plantherbivore interactions are active principals for industrial pharmaceuticals.

\section{MATERIAL AND METHODS}

Rev. Bras. Farmacogn.

Braz J. Pharmacogn.

16(3):jul/set. 2006

\section{Study area}

Research was carried out in a 20 ha. fragment of arboreal caatinga within the "Empresa Pernambucana de Pesquisa Agropecuária" (IPA) Experimental Station, Pernambuco State, Brazil (Figure 1) (8¹4'18" S, $\left.35^{\circ} 55^{\prime} 20^{\prime \prime} \mathrm{W}\right)$ at $537 \mathrm{~m}$ a.s.l. The area is located ca. $9 \mathrm{~km}$ 


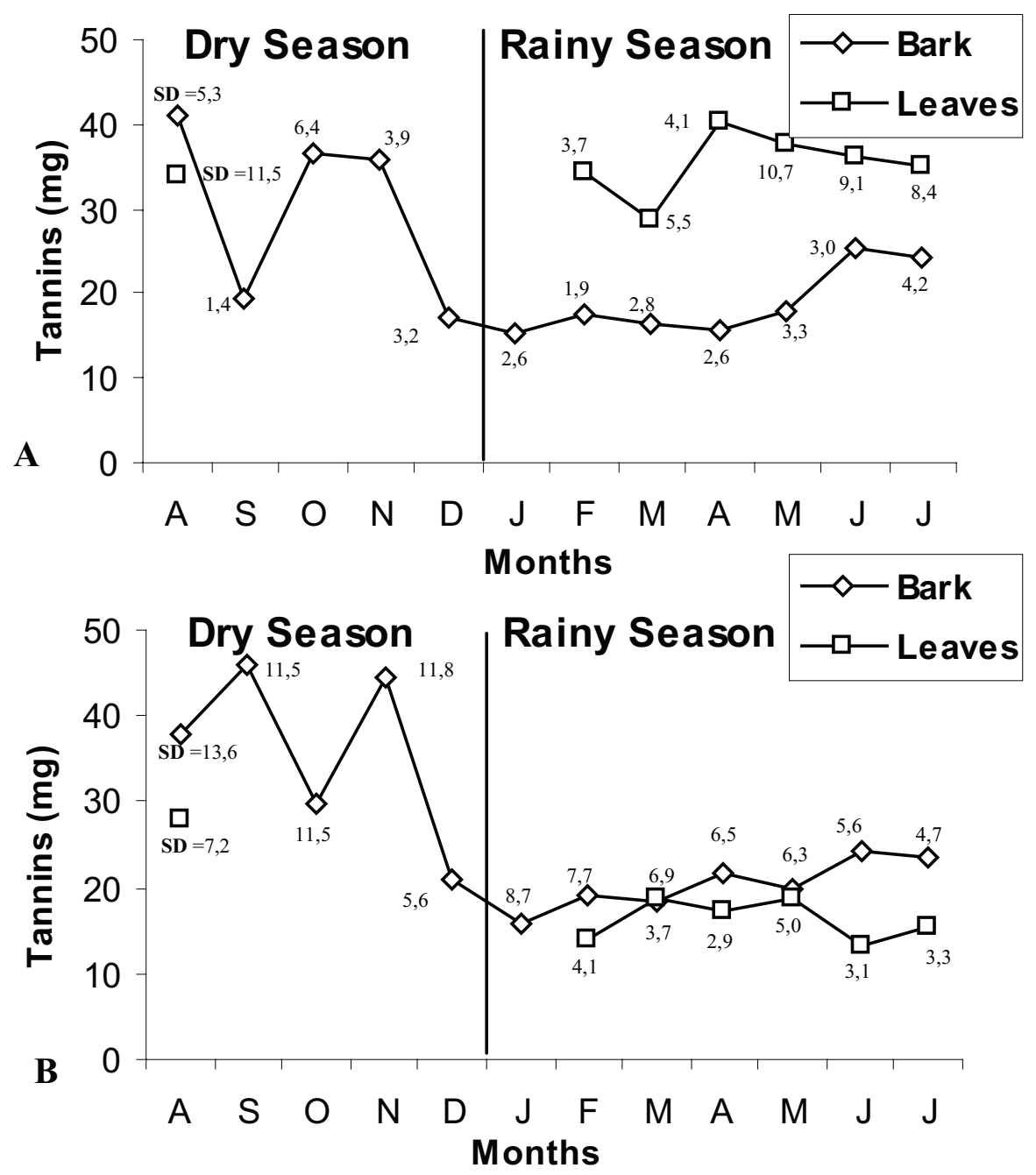

Figure 2. Variation in tannin levels in $500 \mathrm{mg}$ samples of bark and leaves of Myracrodruon urundeuva (Engl.) Fr. All. (A) and Anadenanthera colubrina (Vell.) Brenan (B) in response to seasonal changes during 2003/2004 in a caatinga fragment in Pernambuco State, Brazil. SD = Standard deviation.

northeast of the city of Caruaru, and approximately 150 $\mathrm{km}$ from the state capital of Recife. The soils there are predominantly eutrophic, yellow Podzols tb, abrupt, A moderate (Alcoforado-Filho et al., 2003). The dry season was considered as falling between August and December 2003, as in January of 2004 there was a total rainfall of $240 \mathrm{~mm}$, with only slightly less rainfall occurring in the following months (Figure 1) of the rainy season. It is important to note that the uncharacteristically heavy rainfall during this wet season was quite atypical for the region. The vegetation at the research site is deciduous and spiny, and comprises ca. 105 species, distributed among 41 families, including herbaceous plants, vines, subshrubs, shrubs, and trees. Some of the most conspicuous arboreal elements belong to the families Anacardiaceae and Caesalpiniaceae (Alcoforado-Filho et al., 2003). Vegetative material was collected at monthly intervals between August 2003 and July 2004, with the exception of mature leaves, which were collected in August 2003 and from January to July of 2004.

The species Myracrodruon urundeuva (Engl.) Fr. All. (common name: Aroeira) and Anadenanthera colubrina (Vell.) Brenan (common name, Angico), were selected for analysis because of the large number of individuals present in the area, and their importance in local traditional medicine (Albuquerque and Andrade, 2002a,b; Macedo; Ferreira, 2004). Ten individuals of each species within previously established permanent plots (covering a total of one hectare) at the experimental station (Araújo, 1998) were designated for monitoring. Individuals were selected according to the following criteria: $\mathrm{DBH}>35 \mathrm{~cm}$, height $>3.5 \mathrm{~m}$. Monthly collections of trunk bark and mature leaves (ca. 5 grams each) were made to analyze tannin levels. Leaves were preferentially collected from the same position on all trees, and care was taken in selecting material that was intact and without signs of predation, and in the same development stage. Bark was harvested from between 50 and $120 \mathrm{~cm}$ above

Rev. Bras. Farmacogn. Braz J. Pharmacogn 16(3):jul/set. 2006 

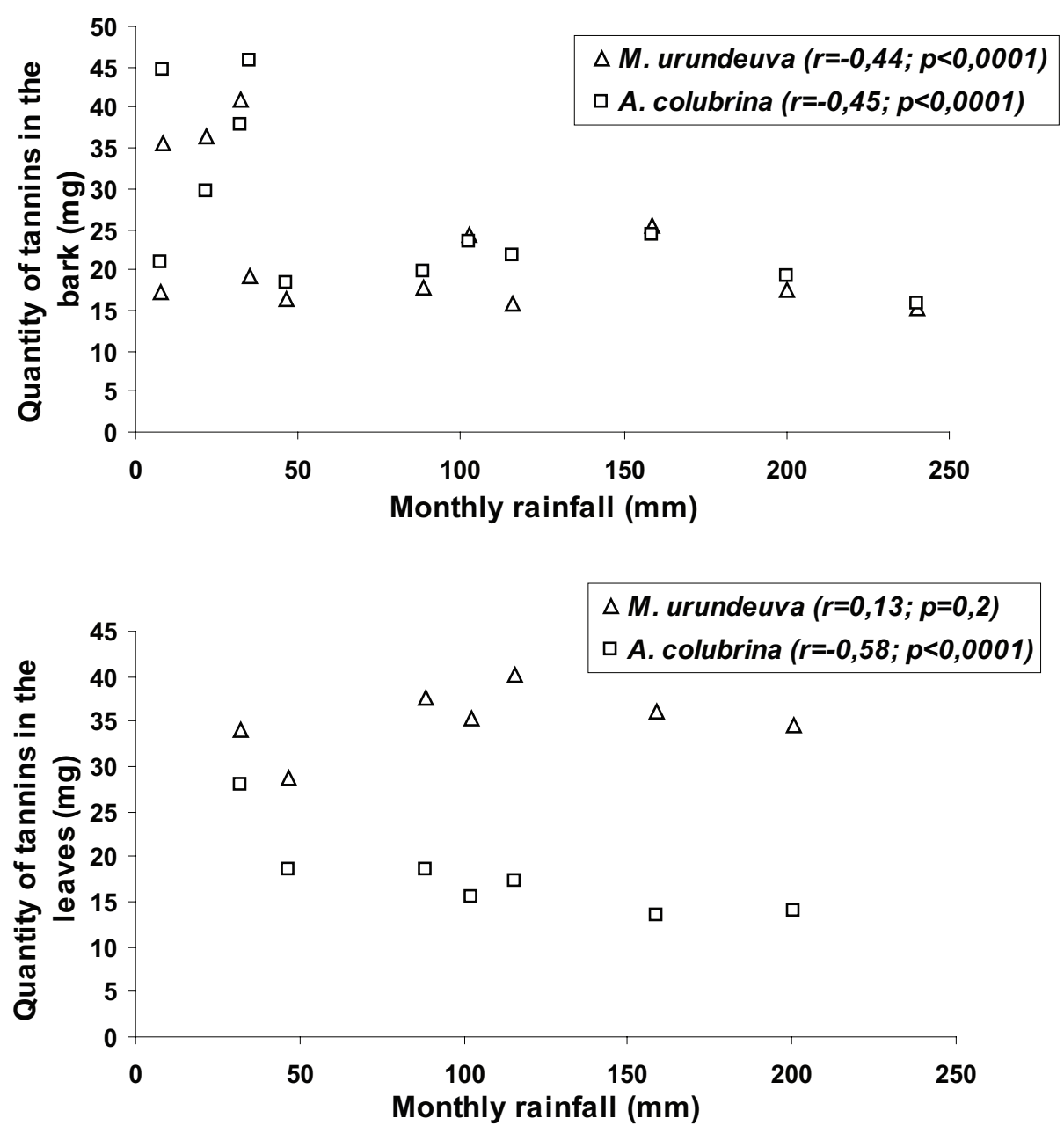

Figure 3. Correlation between the quantities of tannins in $500 \mathrm{mg}$ samples of the bark and leaves of Myracrodruon urundeuva (Engl.) Fr. All. and Anadenanthera colubrina (Vell.) Brenan in relation to the rainfall during 12 months (2003/2004) in a caatinga fragment in Pernambuco State, Brazil.

ground level.

Preparation of extracts and quantification of phenol and tannin levels

All plant material collected in the field was placed in paper envelopes for transport to the laboratory. Bark was dried for three days at $50{ }^{\circ} \mathrm{C}$ in a drying oven, while leaves were dried at room temperature (except on rainy days, when these also were treated in a drying oven at $\left.50{ }^{\circ} \mathrm{C}\right)$. Methanol extracts $(80 \% \mathrm{v} / \mathrm{v})$ were made of the bark and leaf samples, at the proportion of 500 $\mathrm{mg}$ of plant material to $5 \mathrm{~mL}$ of solvent. Five successive extractions were performed, heating the solvent each time to the initiation of boiling. All extractions were performed in triplicate. Total phenolic compounds present in the extracts were analyzed using the FolinCiocalteau method, and total tannins assayed by the casein precipitation technique (Folin; Ciocalteau, 1927;
Seigler et al., 1986; Mueller-Harvey, 2001; Readel et al., 2001; Queiroz et al., 2002). The Folin-Ciocalteau method employed in this study to measure total phenolic compounds consisted of adding $0.25-0.5 \mathrm{~mL}$ of the extract to $75 \mathrm{~mL}$ of distilled water, $5 \mathrm{~mL}$ of the FolinCiocalteau reagent (in aqueous solution at $10 \%-\mathrm{v} / \mathrm{v}$ ), $10 \mathrm{~mL}$ of aqueous sodium carbonate $(0.75 \%-\mathrm{m} / \mathrm{v})$, and then completing the final volume to $100 \mathrm{~mL}$ with distilled water. The resulting solution was stirred mechanically for three hours at room temperature, and then left to settle for 30 minutes. Absorbance of the supernatant was measured at $760 \mathrm{~nm}$ in a spectrophotometer. Absorption measurements were calibrated against control solutions of tannic acid at concentrations of $0.1 ; 0.5 ; 1.0 ; 2.5$ and $3.75 \mu \mathrm{g} . \mathrm{mL}^{-1}$.

Total tannin concentrations were determined by the casein precipitation method, which consists of adding $1 \mathrm{~g}$ of powdered casein to $6 \mathrm{~mL}$ samples of extracts diluted with $12 \mathrm{~mL}$ of distilled water. The resulting solution was 
agitated for three hours at room temperature $\left(25^{\circ} \mathrm{C}\right)$, after which it was filtered through $9 \mathrm{~cm}$ Whatman filter paper and the filtrate adjusted to $25 \mathrm{~mL}$ final volume. Aliquots $(8 \mathrm{~mL}-12 \mathrm{~mL}$ ) of this solution where then tested for residual phenolic compounds using the Folin-Ciocalteau method. The quantity of tannins corresponds to the difference in the absorption of these casein precipitated samples and those obtained in the total phenol analysis. The quantity of total phenols and tannins are expressed per mg of dry material.

\section{Data analysis}

The Kolmogorov-Smirnov test was used to examine the normality of the data (Zar, 1996). The Kruskal-Wallis test was employed to reveal differences in tannin concentrations of the two species during different seasons. In order to evaluate the correlation between tannin concentrations in the two species and rainfall averages, the Spearman correlation coefficient was used. All statistical analyses were performed using BioEstat 2.0 software (Ayres et al., 2000).

\section{RESULTS}

\section{Tannin $\mathrm{x}$ season}

The bark and leaves of $A$. colubrina concentrate more tannins during the dry season than during the rainy season $(H=33.51 ; \mathrm{P}<0.0001$ and $H=18.89$; $\mathrm{P}$ $<0.0001$, respectively). The bark shows higher tannin concentrations than do the leaves during the rainy season $(H=14.43 ; \mathrm{P}=0.0001)$ (Figure 2). Likewise, trunk bark of $M$. urundeuva concentrated more tannins during the dry season than during the rainy season $(H=29.97$; $\mathrm{P}$ $<0.0001)$. There was no observed difference in tannin concentrations in the leaves of this species during the different seasons $(H=0.11 ; \mathrm{P}=0.73)$. The leaves of $M$. urundeuva demonstrated higher tannin concentrations than the bark during the rainy season $(H=79.64$; $\mathrm{P}<$ 0.0001) (Figure 2).

The bark of $A$. colubrina had greater tannin concentrations than the bark of $M$. urundeuva during the dry season $(H=3.98 ; \mathrm{P}=0.04)$, however, the leaves of M. urundeuva had greater tannin concentrations than $A$. colubrina leaves during the rainy season $(H=82.54$; $\mathrm{P}<$ 0.0001 ) (Figure 2). The tannin concentrations in the bark of the two species were similar during the rainy season.

\section{Tannins x rainfall}

The concentrations of tannics compounds in the bark of $M$. urundeuva and A. colubrina were negatively correlated with rainfall $(r=-0.44 ; \mathrm{P}<0.0001$ and $r=$ $-0.45 ; \mathrm{P}<0.0001$, respectively) (Figure 3 ). The same negative correlation was observed with the leaves of $A$. colubrina $(r=-0.58 ; \mathrm{P}<0.0001)$ during the rainy season.
There was no observed relationship between tannin levels and rainfall in leaves of M. urundeuva (Figure 3).

\section{DISCUSSION}

\section{Tannins and seasonality}

The resource availability hypothesis (Coley et al., 1985) appears to explain the fact that the greatest concentrations of tannins where found in the trunk bark of the two species examined, as well as in the leaves of $A$. colubrina, during the dry season. It is not able to explain, however, the lack of seasonal differences in leaf tannin concentrations in M. urundeuva. Although this hypothesis attempts to explain this phenomenon in a very general manner (Horner, 1990; Kouki; Manetas, 2002; Barone; Coley, 2002), its predictions have generally been borne out. It has been observed that plants growing on fertile soils produce higher levels of phenolic compounds than plants growing on poor soils, although no variations have been reported in levels of condensed tannins under these conditions (Barone; Coley, 2002). Makkar and Becker (1998), for example, encountered high tannin levels in species belonging to the group Leguminosae strictu sensu in areas where the climate is severe and water resources are limited. In Ceratonia siliqua L. Kouki and Manetas (2002) found that leaves of water stressed plants had higher levels of total phenolics and tannins, especially in young leaves. However, only condensed tannins were decreased by nutrient addition while both condensed and gallotannins were increased by water stressed (Kouki; Manetas, 2002). Periods of high temperature may stimulate the synthesis of tannins by favoring the shikimate pathway, a precursors of these compounds (Makkar; Becker, 1998; González-Hernandez et al., 2000; Gebrehiwot et al., 2002; Riipi et al., 2002).

During the rainy season, $M$. urundeuva exhibited elevated tannin concentrations in its leaves, as compared to its bark. This strategy seems similar to that encountered in Didymopanax vinosum (Cham. \& Scldl.) Seem. (a Brazilian cerrado plant that demonstrates its highest levels of tannin concentrations when growing in forest formations under more humid conditions) (Pais; Varanda, 2003). However, the behavior of $A$. colubrina was exactly the opposite of that observed for M. urundeuva, as greater amounts of tannins would have been expected to be found in the leaves during the rainy season due, to both a greater photosynthetic capacity and greater herbivore pressure. Perhaps the results observed for A. colubrina were due to investments in non-tannin plant defenses during this period, as toxicity in this plant is more related to the presence of nitrogen-based cyanogenic glycosides (Tokarnia et al., 1999). In the case of A. colubrina, however, the observed synthesis of cyanogenic glycosides may well be related to the fact that this group of plants harbors bacterial and fungal symbionts. These organisms fix atmospheric nitrogen that can subsequently be used

Rev. Bras. Farmacogn. Braz J. Pharmacogn 16(3):jul/set. 2006 
for defensive purposes (Mendonça; Schiavinato, 1996; Gross et al., 2002; Patreze; Cordeiro, 2004).

Tannins may respond quantitatively or qualitatively to season patterns, and it would be interesting to investigate how condensed and hydrolyzed tannin compounds vary in each of the species examined. Hatano et al. (1986) observed that telimagrandin II (a hydrolysable tannin) is abundant in leaves during the spring in Liquidambar formosana Hance, but decreases rapidly to minimal amounts in the summer. On the other hand, casuarinin and pedunculaginin (also hydrolysable tannins) are abundant during the summer and fall. In species of Quercus, an increase in the composition of low molecular weight compounds and a decrease in elagitanin monomers and dimmers occurs before and after one year (Simon et al., 1999).

\section{ACKNOWLEDGEMENTS}

The authors would like to thank the Empresa Pernambucana de Pesquisa Agropecuária (IPA) experimental station in Caruaru, Pernambuco State, and especially its director, Mr. Jair Pereira for logistical support; Ruth R. Strattmann, technician of the "Núcleo de Controle de Qualidade e Medicamentos Correlatos", Depto. de Ciências Farmacêuticas da Universidade Federal de Pernambuco, for her valuable contributions in the techniques of tannin analyses; to the CNPq/FACEPE for financial support for U.P. Albuquerque as part of the Primeiros Projetos project; and to CAPES for a research grant to the first author.

\section{REFERENCES}

Albuquerque UP, Andrade LHC 2002a. Conhecimento botânico tradicional e conservação em uma área de caatinga no Estado de Pernambuco, Nordeste do Brasil. Acta Botanica Brasilica 16: 273-285.

Albuquerque UP, Andrade LHC 2002b. Uso de recursos vegetais da caatinga: o caso do agreste do Estado de Pernambuco (Nordeste do Brasil). Interciencia 27: 336-345.

Alcoforado-Filho FG, Sampaio EVSB, Rodal MJN 2003. Florística e fitossociologia de um remanescente de vegetação caducifólia espinhosa arbórea em Caruaru, Pernambuco. Acta Botanica Brasilica 17: 287-303.

Araújo EL 1998. Aspectos da dinâmica populacional de duas espécies em floresta tropical seca (caatinga), Nordeste do Brasil. Tese de Doutorado Universidade Estadual de Campinas.

Ayres M, Ayres MJ, Ayres DL, Santos SA 2000. Bioestat 2.0: aplicações estatísticas nas áreas das ciências biológicas e médicas. Brasília: Sociedade Civil Mamirauá, CNPq.

Barone JA, Coley PD 2002. Herbivorismo y las defensas de las plantas. In: Guariguata, M.R., Kattan, G. H. (orgs.) Ecología y conservación de bosques neotropicales. Cartago: Ediciones LUR p. 465-493. 692p.
Castelletti CHM, Santos AMM, Tabarelli M, Silva MCS 2003. Quanto ainda resta da caatinga? Uma estimativa preliminar. In: Leal, I.R., Tabarelli, M., Silva, J.M.C. (Orgs.) Ecologia e conservação da caatinga. Ed. Universitária, UFPE.

Coley PD, Bryant JP, Chaplin IFS 1985. Resourse availability and plant anti-herbivore defense, Science 230: 895899.

Fernandes A 2002. Biodiversidade da Caatinga. In: Araújo, E.L., Moura, A.N.; Sampaio, E.S.B., Gestinari, L.M.S., Carneiro, J.M.T. (Orgs.) Biodiversidade, Conservação e Uso Sustentável da Flora do Brasil. Imprensa Universitária: UFRPE. p. 42-44. 262 p.

Folin O, Ciocalteau V 1927. On tyrosine and tryptophane determination in proteins. $J$ Biol Chem 73: 424427.

Furlan CM, Domingos M, Salatino A 1999. Leaf contents of nitrogen and phenolic compounds and their bearing with the herbivore damage to Tibouchina pulchra Cogn. (Melastomataceae), under the influence of air pollutants from industries of Cubatão, São Paulo. Revista Brasileira de Botânica 22: 317-323.

Gebrehiwot L, Beuselink PR, Roberts CA 2002. Seasonal variations in condensed tannins concentration of three Lotus species. Agron J 94: 1059-1065.

Giulietti AM, Harley RM, Queiroz LP, Barbosa MRV, Neta ALB, Figueiredo MA 2002. Espécies Endêmicas da Caatinga. In: Sampaio, E.V.S.B., Giulietti, A.M., Virgínio, J., Gamarra-Rojas, C.F.L. (Orgs.) Vegetação e flora da caatinga. APNE - CNIP. p. 103-119. 176p.

González-Hernández MP, Starkey EE, Karchesy J 2000. Seasonal variation in concentrations of fiber, crude protein and phenolic compounds in leaves of red alder (Alnus rubra): nutritional implications for cervids. J Chem Ecol 26: 293-301.

Gross E, Cordeiro L, Caetano FH 2002. Nodule ultrastructure and initial growth of Anadenanthera peregrina (L.) Speg. var. falcata (Benth.) Altschul. plants infected with rhizobia. Ann Bot 90: 175-183.

Hatano T, Kira R, Yoshizaki M, Okuda T 1986. Seasonal changes in the tannins of Liquidambar formosana reflectings their biogenesis. Phytochemistry 25: 2787-2789.

Horner JD 1990. Nonlinear effects of water deficits on foliar tannin concentration. Biochem Syst Ecol 18: 211213.

Kouki M, Manetas Y 2002. Resource availability affects differentially the levels of gallotannins and condensed tannins in Ceratonia siliqua. Biochem Syst Ecol 30: 631-639.

Macedo M, Ferreira AR 2004. Plantas medicinais usadas para tratamento dermatológicos, em comunidades da Bacia do Alto Paraguai, Mato Grosso. Rev Bras Farmacogn 14(Supl. 1): 40-44.

Makkar HPS, Becker K 1998. Do tannins in leaves of tree and shrubs from African and Himalayan regions differ in level and activity? Agroforestry Syst 40: 59-68.

Mendonça EHM, Schiavinato MA 1996. Effect of different sources and concentrations of mineral nitrogen on growth and nodulation of two angico species. Arquivos de Biologia e Tecnologia 39: 607-611.

Monteiro JM, Lins-Neto EMF, Amorim ELC, Strattmann RR, Araújo EL, Albuquerque UP 2005a. Teor de taninos 
em três espécies medicinais arbóreas simpátricas da caatinga. Revista Árvore 29: 999-1005.

Monteiro JM, Albuquerque UP, Lins-Neto E MF, Araújo EL, Amorim ELC 2005b. Use patterns and knowledge of medicinal species among two rural communities from northeastern Brazil's semi-arid region. $J$ Ethnopharmacol In press. Available on line.

Monteiro JM, Almeida CFCBR, Albuquerque UP, Lucena RFP, Florentino ATN, Oliveira RLC 2006. Use and traditional management of Anadenanthera colubrina (Vell.) Brenan in the semi-arid region of northeastern Brazil. Journal of Ethnobiology and Ethnomedicine 2: 1-18.

Mueller-Harvey I 2001. Analysis of hydrolysable tannins. Anim Feed Sci Techn 91: 3-20.

Pais MP, Varanda EM 2003. Variation in plant defenses of Didymopanax vinosum (Cham. \& Schltdl.) Seem. (Apiaceae) a vegetation gradient in a Brazilian cerrado. Acta Botanica Brasilica 17: 395-403.

Paiva SR, Heringer AP, Figueredo MR, Kaplan MAC 2002. Taninos condensados de espécies de Plumbaginaceae. Floresta e Ambiente 9: 153-157.

Pansera MR, Santos ACA, Paese K, Wasum R, Rossato M, Rota LD, Pauletti GF, Serafini LA 2003. Análise de taninos totais em plantas aromáticas e medicinais cultivadas no Nordeste do Rio Grande do Sul. Rev Bras Farmacogn 13: 17-22.

Patreze CM, Cordeiro L 2004. Nitrogen-fixing and vesiculararbuscular mycorrhizal symbioses in some tropical legume trees of tribo Mimoseae. Forest Ecol Manag 196: 275-285.

Queiroz CRAA, Morais SAL, Nascimento EA 2002. Caracterização dos taninos da aroeira-preta (Myracrodruon urundeuva). Revista Árvore 26: 485-492

Readel K, Seigler D, Hwang K, Kessy J 2001. Tannins from mimosoid legumes of Texas and México. Econ Bot 55: 212-222.

Riipi M, Ossipov V, Lempa K, Haukioja E, Koricheva J, Ossipova S, Pihlaja K 2002. Seasonal changes in birch leaf chemistry: are there trade-offs between growth and accumulation of phenolics?. Oecologia 130: 380-390.

Salminen J, Ossipov V, Haukioja E, Pihlaja K 2001. Seasonal variation in the content of hydroyisable tannins in leaves of Betula pubescens. Phytochemistry 57: 1522.

Seigler DS, Seilheimer S, Keesy J, Huang HF 1986. Tannins from four common Acacia species of Texas and Northeastern Mexico. J Sci Food Agr 29: 778-794.

Simon BF, Cadahia E, Conde E 1999. Evolution of phenolic compounds of spanish oak wood during natural seasoning. First results. J Agr Food Chem 47: 16871694.

Teixeira ML, Soares AR, Scolforo JRS 1990. Variação do teor de tanino da casca de barbatimão [Stryphnodendron adstringens (Mart.) Coville] em 10 locais de Minas Gerais. Ciência Prática de Lavras 14: 229-232.

Tokarnia CH, Peixoto PV, Brito ME, Duarte MD, Brust LAC 1999. Estudos - experimentais com plantas cianogênicas em bovinos. Pesquisa Veterinária Brasileira 9: 84-90.

Yariwake JH, Lanças FM, Cappelaro EA, Vasconcelos EC,
Tiberti LA, Pereira AMS, Franca SC 2005. Variabilidade sazonal de constituintes químicos (triterpenos, flavonóides e polifenóis) das folhas de Maytenus aquifolium Mart. (Celastraceae). Rev Bras Farmacogn 15: 162-168.

Zar JH 1996. Bioestatistical analysis. London: Prentice-Hall. 